\section{Immunofluorescence characterization of innervation and nerve-immune cell interactions in mouse lymph nodes}

\author{
Dailun Hu, ${ }^{1}$ Philip K. Nicholls, ${ }^{2}$ \\ Melissa Claus, ${ }^{3}$ Yongkang Wu, ${ }^{4}$ \\ Zhongli Shi, ${ }^{1}$ Wayne K. Greene, ${ }^{2}$ \\ Bin $\mathrm{Ma}^{2}$ \\ ${ }^{1}$ Clinical College, Hebei Medical \\ University, Shijiazhuang, China \\ ${ }^{2}$ Medical, Molecular and Forensic \\ Sciences, Murdoch University, Murdoch, \\ WA, Australia \\ ${ }^{3}$ School of Veterinary Medicine, \\ Murdoch University, Murdoch, WA, \\ Australia \\ ${ }^{4}$ Department of Laboratory Medicine, \\ West China Hospital, Sichuan \\ University, Chengdu, China
}

\begin{abstract}
The peripheral nervous system communicates specifically with the immune system via local interactions. These interactions include the "hardwiring" of sympathetic/ parasympathetic (efferent) and sensory nerves (afferent) to primary (e.g., thymus and bone marrow) and secondary (e.g., lymph node, spleen, and gut-associated lymphoid tissue) lymphoid tissue/organs. To gain a better understanding of this bidirectional interaction/crosstalk between the two systems, we have investigated the distribution of nerve fibres and PNS-immune cell associations in situ in the mouse lymph node by using immunofluorescent staining and confocal microscopy/ three-dimensional reconstruction. Our results demonstrate: i) the presence of extensive nerve fibres in all compartments (including B cell follicles) in the mouse lymph node; ii) close contacts/associations of nerve fibres with blood vessels (including high endothelial venules) and lymphatic vessels/sinuses; iii) close contacts/associations of nerve fibres with various subsets of dendritic cells (e.g., $\mathrm{B} 220^{+} \mathrm{CD} 11 \mathrm{c}^{+}, \quad \mathrm{CD} 4{ }^{+} \mathrm{CD} 11 \mathrm{c}^{+}, \quad \mathrm{CD}^{2} \mathrm{a}^{+}$ $\mathrm{CD} 11 \mathrm{c}^{+}$, and $\left.\mathrm{Mac}^{+} \mathrm{CD} 11 \mathrm{c}^{+}\right), \mathrm{Mac}^{+}$ macrophages, and B/T lymphocytes. Our novel findings concerning the innervation and nerve-immune cell interactions inside the mouse lymph node should greatly facilitate our understanding of the effects that the peripheral nervous system has on cellular- and humoral-mediated immune responses or vice versa in health and disease.
\end{abstract}

\section{Introduction}

The human body systems work together to maintain internal stability and balance or equilibrium, a state known as homeostasis. ${ }^{1}$ For example, the nervous system [including the central nervous system (CNS) and the peripheral nervous system (PNS)] and the immune system, which are the principal sensory interfaces between the internal and external environment, collaborate to maintain homeostasis and to protect the host against disease or other potentially damaging foreign substances..$^{2-5}$

The nervous system regulates hematopoiesis, priming, migration and the cytokine production of immune cells by the secretion of hormones from the pituitary/other endocrine organs and via the direct innervation of the immune organs..$^{5-9}$ Interestingly, the immune response can also have various impacts on homeostatic neural circuits such as those controlling blood pressure, metabolism, body temperature, and inflammatory reflex. ${ }^{2,5}$

Recent studies have addressed the bidirectional crosstalk of the PNS and immune system by using several in vivo and in vitro approaches including cell-specific targeting, novel sequencing, imaging and analytical tools to reveal the mechanisms of neuroimmune regulation. ${ }^{7-9}$ This bidirectional crosstalk has been studied in two directions: the PNS-mediated regulation of immunity and the immune-system-mediated regulation of PNS function. The same molecules, including cytokines, neurotransmitters, and trophic factors, participate as mediators in both directions. $^{7}$

The PNS communicates specifically with the immune system according to local interactions, including the "hardwiring" of sympathetic/parasympathetic (efferent) and sensory nerves (afferent) to primary (including thymus and bone marrow) and secondary lymphoid organs (including lymph node, spleen, and gut-associated lymphoid tissue)..$^{10-15}$ Both classic (catecholamines and acetylcholine) and peptide neurotransmitters released by sympathetic/parasympathetic nerve endings (or even by immune cells) bind to their respective receptors on the surface of immune cells and initiate immune-modulatory responses. ${ }^{5-7,16}$ Cytokines synthesized/ released by the immune cells (or even neurons/glial cells) have effects on nervous tissue and act as mediators of immune-system-mediated nervous functions..$^{7,17}$ However, despite the results in the abovementioned reports that have demonstrated the occurrence of functional interconnections between the PNS and immune system, data concerning the mechanisms of this bidirectional crosstalk are frequently
Correspondence: Bin Ma, Medical, Molecular and Forensic Sciences, Murdoch University, 90 South Street, Murdoch, WA 6150, Australia.

Tel. +61.8.93602668 - Fax: +61.8.93104144. E-mail: B.Ma@murdoch.edu.au

Key words: Innervation; lymph node; dendritic cell; lymphocytes; neurofilament; immunofluorescence staining.

Contributions: DH, WKG, and BM conceived the study, designed the experiments, and wrote the paper. $\mathrm{DH}, \mathrm{PKN}, \mathrm{MC}, \mathrm{YW}, \mathrm{ZS}$, and $\mathrm{BM}$ performed experiments and analysed the data. All authors discussed the results, provided comments, and reviewed the manuscript.

Conflict of interest: None of the authors has a conflict of interest to declare.

Acknowledgements: The authors would like to thank Wayne Rasband for the ImageJ program.

Received for publication: 17 July 2019.

Accepted for publication: 1 October 2019.

This work is licensed under a Creative Commons Attribution-NonCommercial 4.0 International License (CC BY-NC 4.0).

(C) Copyright: the Author(s), 2019

Licensee PAGEPress, Italy

European Journal of Histochemistry 2019; 63:3059 doi:10.4081/ejh.2019.3059

incomplete and do not always focus on their relevance to neuroimmune modulation in vivo in health and disease.

The initiation of adaptive immune responses depends upon the careful maneuvering of antigen and lymphocytes into and within strategically placed lymph nodes. ${ }^{18}$ Several approaches including histochemistry, immunohistochemistry/immunofluorescent staining, and retrograde tracing have been utilized to reveal the innervation and potential neuroregulation of the lymph node..$^{10,14-15}$ The presence and distribution of sympathetic catecholamine fibres in the lymph nodes in various species have been well documented in several studies, although whether a parasympathetic input is present in lymph nodes remains under debate. ${ }^{12}$ In addition, lymph nodes have an afferent sensory innervation since, unlike the thymus and spleen, their immune responses are linked with specific regions of the body and tissue compartments in which the location of an immune challenge is critical for directing the immune system to sites of injury and infection. ${ }^{12}$

In our previous studies, we have demonstrated the presence of non-myelinat- 
ing Schwann cells and Remak fibres (including small nociceptive (C-type) axons, postganglionic sympathetic axons, and some preganglionic sympathetic/ parasympathetic fibres) inside the lymph node. ${ }^{19}$ The nerve fibres normally run along the blood vessels, form plexi around some blood vessels and extend into the parenchyma of the lymph node..$^{13,19}$ In addition, these nerve fibres also have direct close associations with some immune cell populations inside the lymph node, indicating the essential roles of the PNS in the regulation of immunity. ${ }^{13,19}$ Therefore, we hypothesize that interaction/communication between the immune system (e.g., secondary lymphoid tissues/organs including lymph node and spleen) and PNS (e.g., sympathetic, parasympathetic, and enteric nerve system) is based on local nerve-immune cell contact inside these lymphoid tissue/organs. By using immunofluorescent staining and confocal microscopy/three-dimensional (3D) reconstruction, we have investigated the distribution of nerve fibres and PNSimmune cell interactions in situ in the mouse lymph node in order to improve our understanding of the microanatomical basis of the interaction of the PNS and secondary lymphoid organs.

\section{Materials and Methods}

\section{Animals}

C57BL/6 male mice (8-10 weeks old) were bought from the Animal Resources Centre (ARC, Murdoch, WA, Australia). All animal experiments were approved by Murdoch University's Animal Ethics Committee and performed according to Australian laws/guidelines for animal protection. We used eight mice in total for this study.

\section{Section preparation}

Microscope slides $(27 \mathrm{~mm} \times 75 \mathrm{~mm})$ were bought from Thermo Fisher Scientific (Scoresby, Australia). After a brief rinse with $70 \%$ ethanol, slides were treated with $0.01 \%$ poly-L-lysine solution (PLL, Sigma, Castle Hill, Australia) for $10 \mathrm{~min}$ followed by air-drying overnight.

Mice were killed by carbon dioxide followed by cervical dislocation. Mesentery or inguinal lymph nodes were immediately removed, embedded in Tissue-Tek ${ }^{\circledR}$ O.C.T. Compound (ProSciTech, Kinwan, Australia), and frozen quickly in liquid nitrogen. Cryosections $(20 \mu \mathrm{m})$ were then cut by using a Leica CM1850 UV Cryostat (Leica Biosystems, Nussloch, Germany) and mounted on the PLL-treated microscope slides. For each staining, six sections were stained and examined.

\section{Antibodies}

The specificities and sources of antibodies are described in Table 1 .

\section{Immunofluorescent staining}

Tissue sections were rinsed briefly with phosphate-buffered saline (PBS) and then fixed with $4 \%$ paraformaldehyde (PFA, Electron Microscopy Sciences, Hatfield, PA, USA) for $10 \mathrm{~min}$ at room temperature. All washes ( $3 \times 8 \mathrm{~min})$ between steps were performed with washing buffer $(0.02 \%$ Triton X-100 in PBS) at room temperature. After treatment with $0.2 \%$ Triton $\mathrm{X}-100$ in PBS for $3 \mathrm{~min}$, sections were incubated with antibody dilution buffer ( $2 \%$ goat serum in PBS; Sigma) for $20 \mathrm{~min}$ at room temperature in order to block any potential non-specific binding sites to the antibodies. The sections of the experimental group were incubated with primary antibodies overnight at $4{ }^{\circ} \mathrm{C}$. For negative control staining, primary antibodies were omitted, and only antibody dilution buffer was applied. All sections were then incubated with secondary antibodies (pre-incubated $20 \mathrm{~min}$ with $0.5 \%$ mouse serum (Sigma) before application) for $2 \mathrm{~h}$ at room temperature. Finally, slides were mounted with glass coverslips by using Fluorescence Mounting Medium (Dako, North Sydney, Australia). No positive signals were observed when the anti-NF-H antibody was omitted (negative control experiments).

Table 1. Specificities and sources of primary and secondary antibodies.

\begin{tabular}{|c|c|c|c|c|}
\hline $\begin{array}{l}\text { Target (alternative name) } \\
\text { [RRID number] }\end{array}$ & Conjugate & $\begin{array}{l}\text { Species, isotype } \\
\text { and dilution }\end{array}$ & Cells labeled & Company \\
\hline $\begin{array}{l}\text { CD11c } \\
\text { [AB_2562807] }\end{array}$ & & $\begin{array}{l}\text { Armenian hamster } \\
\text { monoclonal IgG 1:500 }\end{array}$ & Dendritic cell & $\begin{array}{l}\text { Stemcell Technologies } \\
\text { (Tullamarine, Australia) }\end{array}$ \\
\hline $\begin{array}{l}\text { B220 (CD45R) } \\
\text { [AB_312987] }\end{array}$ & 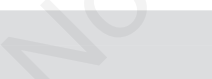 & $\begin{array}{l}\text { Rat monoclonal IgG 1:300 } \\
\text { (Karrinyup, Australia) }\end{array}$ & B cell & Australian Biosearch \\
\hline $\begin{array}{l}\text { CD31 } \\
\text { [AB_312897] }\end{array}$ & 8 & $\begin{array}{c}\text { Rat monoclonal } \\
\text { IgG 1:300 }\end{array}$ & $\begin{array}{l}\text { Blood vessel } \\
\text { endothelial cell }\end{array}$ & Australian Biosearch \\
\hline $\begin{array}{l}\text { CD4 } \\
{[\text { AB_312709] }}\end{array}$ & & $\begin{array}{l}\text { Rat monoclonal } \\
\text { IgG 1:300 }\end{array}$ & T helper cell & Australian Biosearch \\
\hline $\begin{array}{l}\text { CD8a } \\
{[\text { [AB_312763] }}\end{array}$ & & $\begin{array}{l}\text { Rat monoclonal } \\
\text { IgG 1:300 }\end{array}$ & Cytotoxic T cell & Australian Biosearch \\
\hline $\begin{array}{l}\text { Macl (CD11b) } \\
\text { [AB_312785] }\end{array}$ & & $\begin{array}{l}\text { Rat monoclonal } \\
\text { IgG 1:300 }\end{array}$ & Macrophage & Australian Biosearch \\
\hline $\begin{array}{l}\text { Neurofilament } 200 \text { (NF-H) } \\
\text { [AB_477272] }\end{array}$ & & $\begin{array}{l}\text { Rabbit polyclonal } \\
\text { 1:4000 }\end{array}$ & Neuronal marker & $\begin{array}{c}\text { Sigma } \\
\text { (Castle Hill, Australia) }\end{array}$ \\
\hline Rabbit IgG H\&L & Alexa Fluor@ 555 & $\begin{array}{c}\text { Goat polyclonal } \\
\text { 1:1000 }\end{array}$ & & $\begin{array}{c}\text { Abcam Australia } \\
\text { (Melbourne, Australia) }\end{array}$ \\
\hline Armenian Hamster IgG H\&L & Alexa Fluor® 647 & $\begin{array}{l}\text { Goat polyclonal } \\
\text { 1:1000 }\end{array}$ & & Abcam Australia \\
\hline \multirow[t]{2}{*}{ Rat IgG H\&L } & Alexa Fluor ${ }^{\circledR} 488$ & $\begin{array}{c}\text { Goat polyclonal } \\
\text { 1:1000 }\end{array}$ & & Abcam Australia \\
\hline & & $\begin{array}{l}\text { Rabbit IgG from serum } \\
\text { (1:1000 of } 2 \mathrm{mg} / \mathrm{mL} \text { work solution) }\end{array}$ & & Sigma \\
\hline
\end{tabular}


Confocal microscopy and image processing

Confocal microscopy was performed with a Nikon C2 Plus Confocal Microscope (Nikon Instruments, Melville, NY, USA) furnished with three lasers (excitation wavelength at $488 \mathrm{~nm}, 561 \mathrm{~nm}$ and 633 $\mathrm{nm})$. We utilized a Plan Apo $\lambda$ 40x/0.95 dry objective lens and a Plan Apo $\lambda 60 x / 1.40$ oil immersion objective lens for the imaging.
For some experiments, Tile Scan was used to scan a large area of the lymph node. Maximal intensity projection of a Z-stack was performed by using the "Maximal intensity projection" function of the NISElements AR program. The images were then exported as bitmap (BMP) image files and further edited (cropping and labeling) by using Corel PaintShop Pro 2018 (Corel, Ottawa, Canada).

\section{Colocalization analysis with ImageJ}

Colocalization analysis was performed by using the program Image J $1.51 \mathrm{~h}$ (downloaded from https://fiji.sc/) as previously described..$^{20}$ Each RGB image (24-bit) was split into three color channels (8-bit; red, green, and blue). Colocalization analysis was performed by using the "Colocalization Threshold" (in menu PluginsColocalization). The colocalized structures
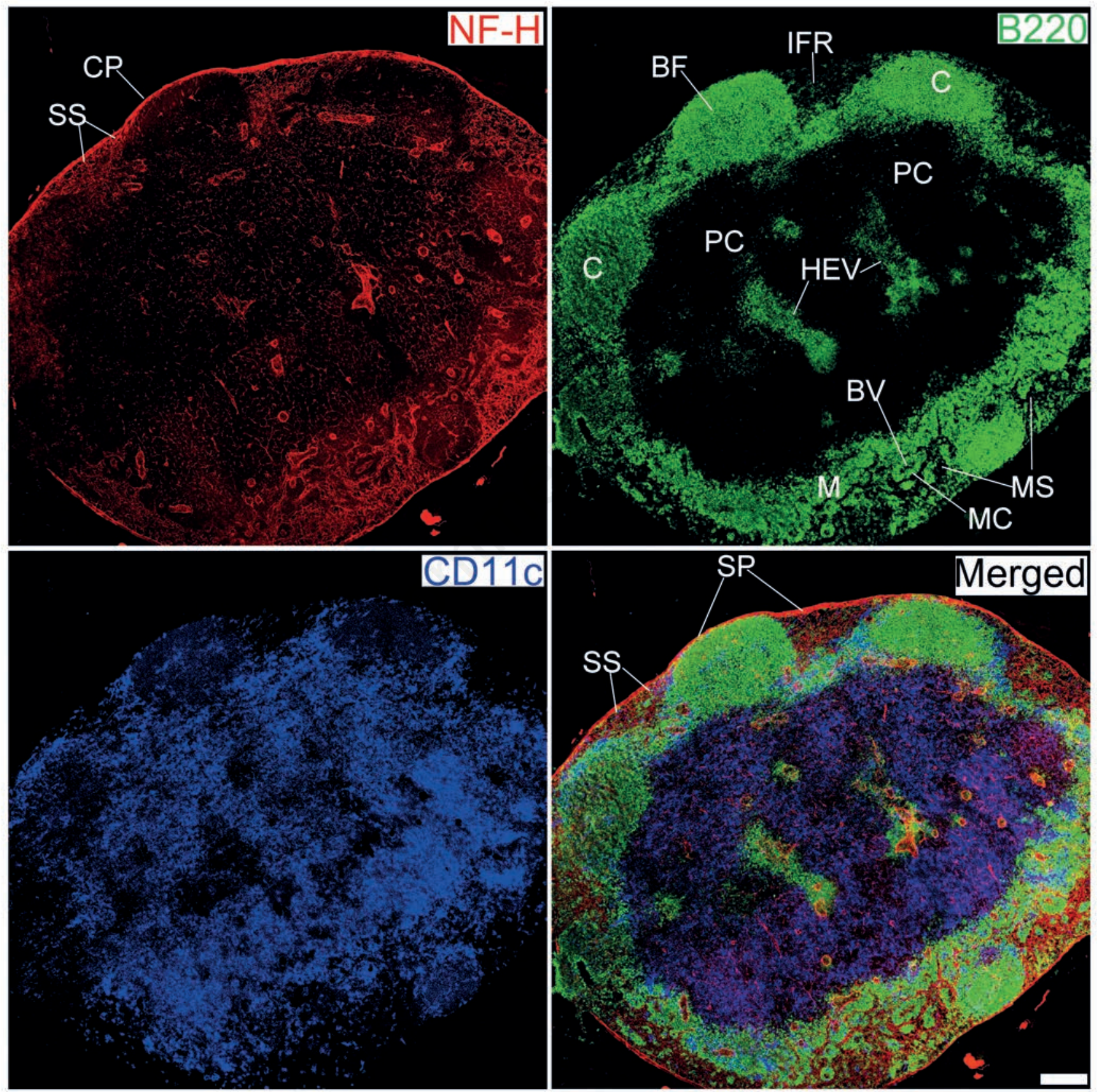

Figure 1. Innervation of a mesenteric lymph node from a C57BL/6 mouse. Antibodies against NF-H (red), B220 (green), and CD11c (blue) label mainly nerve fibres, B cells, and DCs, respectively. CP, capsule; BF, B cell follicle; C, cortex; PC, paracortex; SS, subcapsular sinus; SP, subcapsular plexus; HEV, high endothelial venules; M, medulla; MS, medullary sinus; MC, medullary cord; BV, blood vessel; IFR, interfollicular region. Objective lens: 40x; scanning mode: tile scan; scale bar: $200 \mu \mathrm{m}$. 
appeared white in the final images. The \% intensity above threshold colocalized (Manders' Colocalization Coefficient) for each channel was calculated by the software.
Animation of optic slices and 3D reconstruction with ImageJ

Image sequence (exported from confocal microscopy) was imported into ImageJ and converted to a stack. Volume rendering was performed by using the $3 \mathrm{D}$ viewer (in menu Plugins-3D viewer). After rendering steps, snapshots were taken from the rendered results and saved as TIFF files.

\section{Results}

Distribution of nerve fibres in the mouse lymph nodes

To reveal the distribution of nerve fibres, 20- $\mu$ m-thick cryosections of lymph node from $\mathrm{C} 57 \mathrm{BL} / 6$ male mice were labelled with an anti-neurofilament heavy
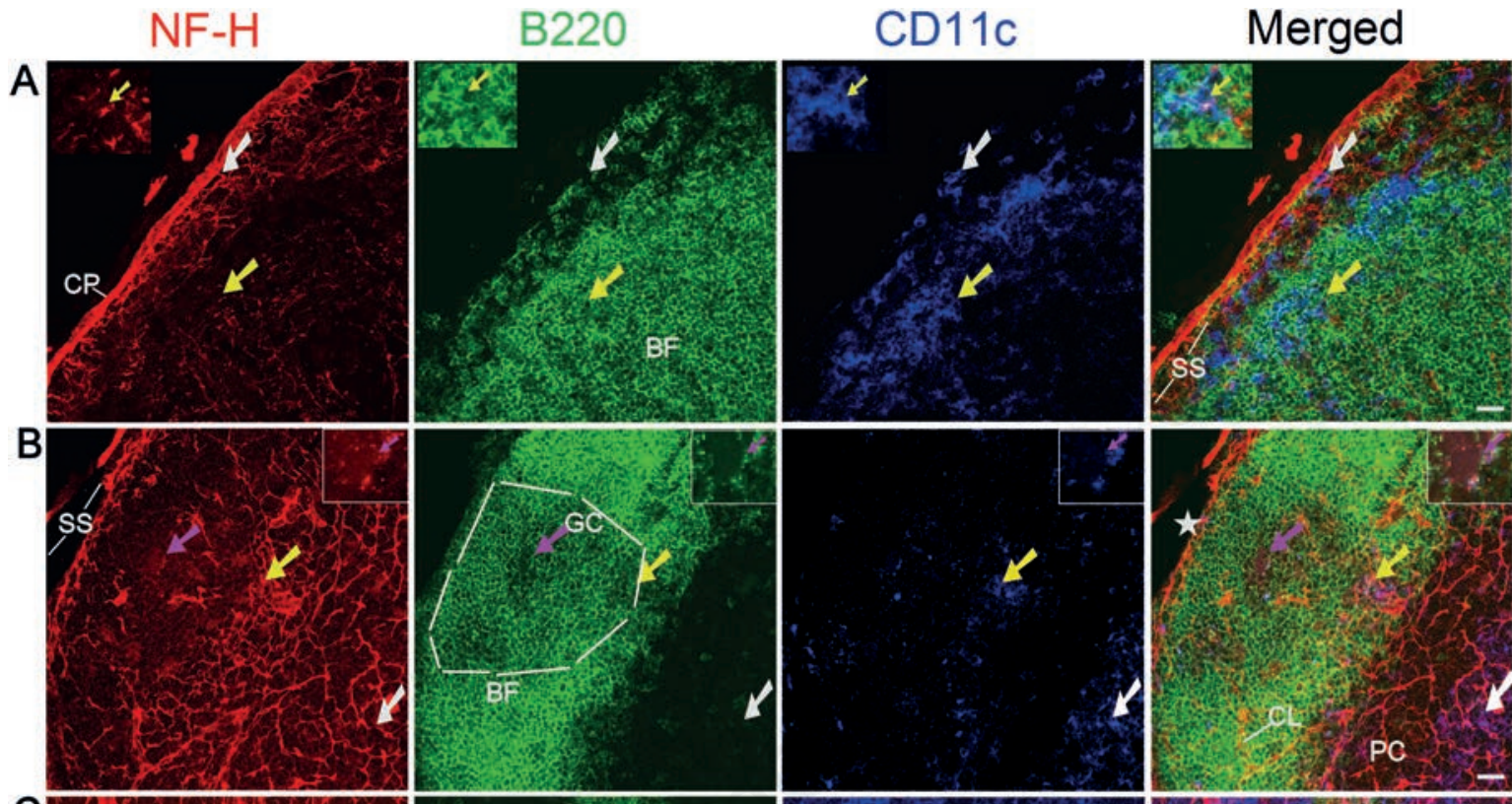

Subcapsular

Sinus /Cortex
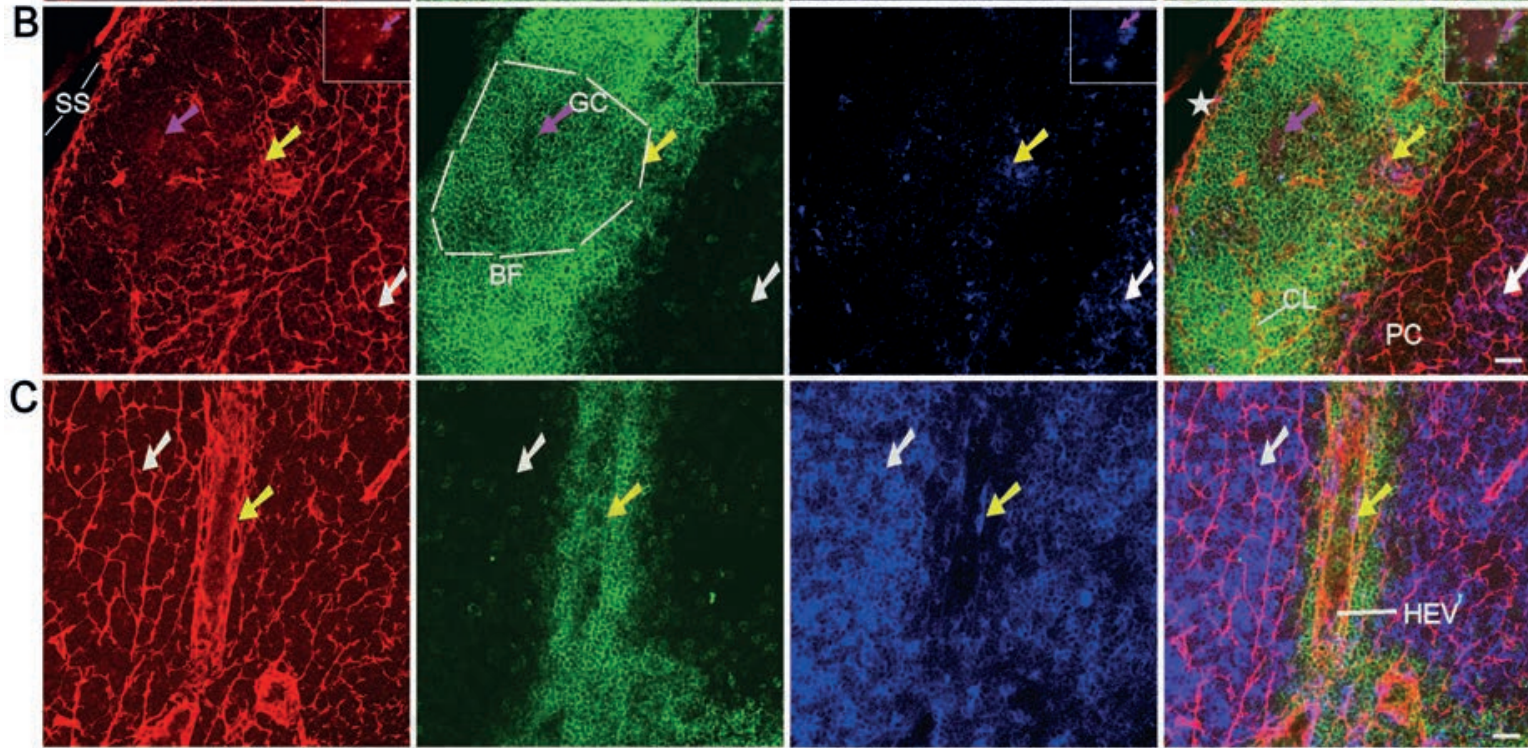

Cortex
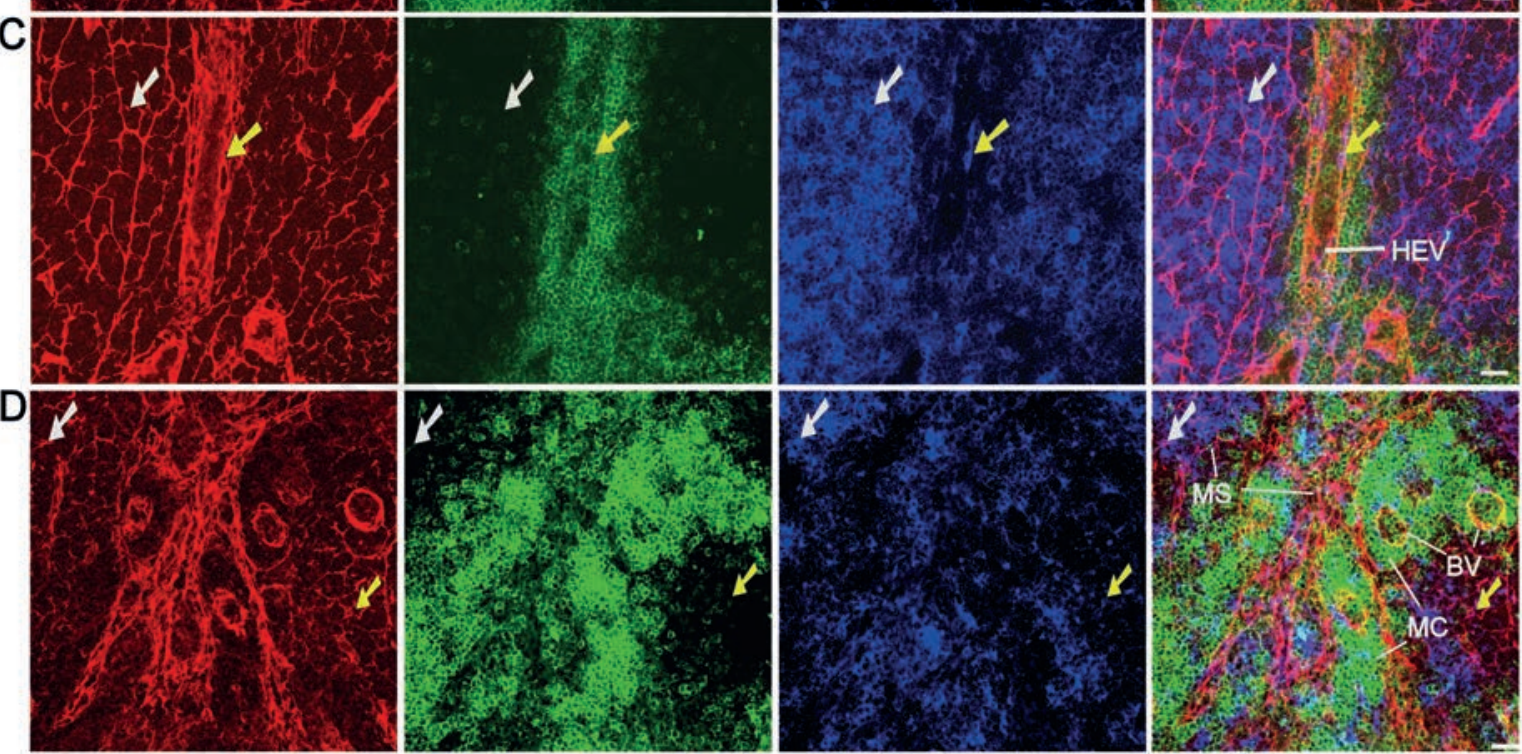

Paracortex

Figure 2. Distribution of nerve fibres in the subcapsular sinus (A), cortex (A-B), paracortex (C), and medulla (D) in the mesenteric lymph node of a C57BL/6 mouse. Antibodies against NF-H (red), B220 (green), and CD11c (blue) label mainly nerve fibres, B cells, and DCs, respectively. The white arrows show B220 CD11 $\mathrm{c}^{+}$DCs that have a close association with the nerve fibres. The yellow arrows indicate $\mathrm{B}_{220^{+}} \mathrm{CD} 11 \mathrm{c}^{+}$DCs that have a close association with the nerve fibres. A) The inserted windows show B220 ${ }^{+} \mathrm{CD} 11 \mathrm{c}^{+}$DC $($also indicated by yellow arrows) that has a close association with the nerve fibres. B) The magenta arrows (also in inserted windows) indicate a few $\mathrm{B}$ cells $\left(\mathrm{B}^{220}{ }^{+} \mathrm{CD} 11 \mathrm{c}^{-}\right)$that have a close association with the nerve endings (appearing as red dots around $\mathrm{B}$ cells). The star indicates a torn site of the subcapsular sinus. The white dashed lines outline the germinal centre (identified from its morphology). All images are generated by using maximum intensity projection of 13 optical slices. Stack size: $6.0 \mu \mathrm{m}$; optical slice interval: $0.5 \mu \mathrm{m}$. CP, capsule; BF, B cell follicle; GC, germinal centre; SS, subcapsular sinus; CL, capillary; HEV, high endothelial venules; PC, paracortex; MS, medullary sinus; MC, medullary cord; BV,: blood vessel.; Objective lens: 40x; scale bar: $20 \mu \mathrm{m}$. 
(NF-H) antibody together with two other antibodies, namely anti-CD11c and antiB220. The results are shown in Figures 1 and 2 and Supplementary Figures 1-4. In control experiments (isotype control with rabbit $\mathrm{IgG}$ and negative control without pri- mary antibody) of NF-H staining, no positive signals were observed (Supplementary Figure 5). An extensive meshwork of nerve fibres was observed in various lymph node compartments, including the capsule/subcapsular region (Figure 2a), cortex (Figure
2 a,b), paracortex (Figure 2c) and medulla (Figure 2d). To understand the innervation of lymph node in other locations, we also performed immunofluorescence staining on mouse inguinal lymph nodes; the results are shown in Supplementary Figure 1.

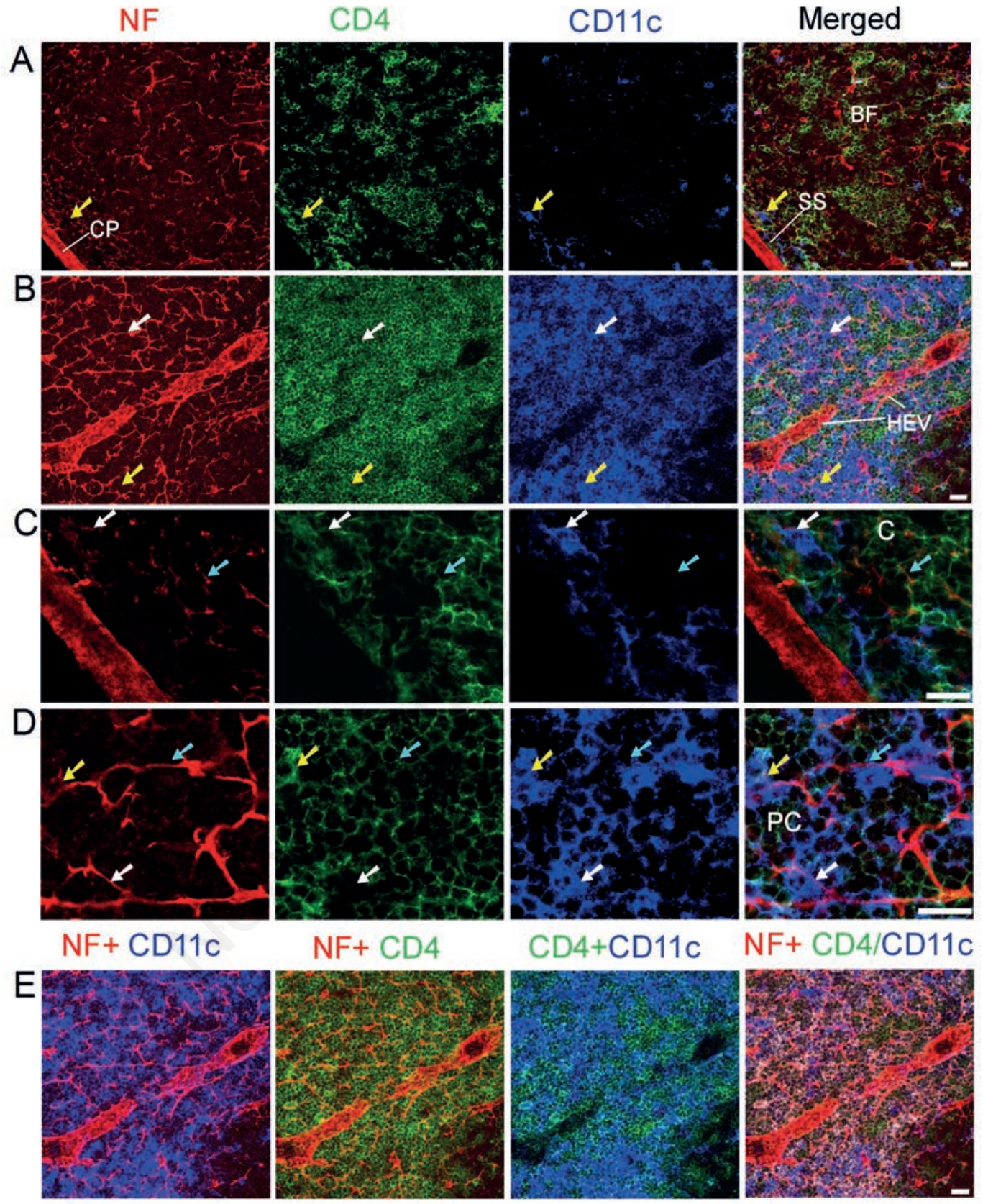

Figure 3. Distribution of nerve fibres, $\mathrm{CD} 4^{+} \mathrm{T}$ helper cells, and DCs in the cortex $(\mathrm{A}, \mathrm{C})$ and paracortex $(\mathrm{B}, \mathrm{D}, \mathrm{E})$ of the mesenteric lymph node of a C57BL/6 mouse. Antibodies against NF-H (red), CD4 (green), and CD11c (blue) label mainly nerve fibres, T helper cells, and DCs, respectively. The cyan arrows show $\mathrm{CD}^{+} \mathrm{T}$ helper cells that have a close association with the nerve fibres. The white arrows show CD4-CD11 ${ }^{+}$DCs that have a close association with the nerve fibres. The yellow arrows indicate $\mathrm{CD}^{+} \mathrm{CD} 11 \mathrm{c}^{+} \mathrm{DCs}$ that have a close association with the nerve fibres. A,B) All images are generated by using maximum intensity projection of 13 optical slices; stack size: $6.0 \mu \mathrm{m}$; optical slice interval: $0.5 \mu \mathrm{m}$. C,D) Images in (C) and (D) are high-resolution views of cropped regions of single optic slice from image sequence of (A) and (B), respectively. E) Combinations of 2 or 3 channels shown in (B). The image in the fourth panel is generated by merging Image I [the red channel (NF)] with Image II (product of colocalization analysis of green and blue channels). The $\mathrm{CD}^{+} \mathrm{CD} 11 \mathrm{c}^{+}$DCs appear white on this image. C, cortex; CP, capsule; BF, B cell follicle; SS, subcapsular sinus; HEV, high endothelial venules; PC, paracortex. Objective lens: 40x; scale bar: $20 \mu \mathrm{m}$. 
Upon breaching the capsule of the lymph node, the contents of the afferent lymphatic vessels are released into the subcapsular sinus, a region between the capsule and cortex. Inside the capsule, nerve fibres that were closely associated with the wall of the subcapsular sinus were observed (Figure 2a). Nerve fibres were also observed within the subcapsular sinus; some of these fibres also had close associations with B cells and dendritic cells (DCs; Figure 2a). The B cell follicles including the germinal centres also contained nerve fibres (Figure $2 \mathrm{a}, \mathrm{b}$ ). In the paracortical region
(Figure 2c), the intensity of nerve fibres was much higher compared with that of the cortex; these nerve fibres also exhibited close associations with some B cells and a large number of DCs $\quad\left(\mathrm{B} 2200^{-} \mathrm{CD} 11 \mathrm{c}^{+}\right.$and $\mathrm{B} 220^{+} \mathrm{CD} 11 \mathrm{c}^{+}$), especially near the high endothelial venules (HEV). Moreover, in the medulla region, nerve fibres were also found to be closely associated with the lymphatic sinus/vessel, blood vessels and $\mathrm{B}$ cells/DCs $\left(\mathrm{B} 220^{-} \mathrm{CD} 11 \mathrm{c}^{+}\right.$and $\mathrm{B} 220^{+} \mathrm{CD} 11 \mathrm{c}^{+}$ DCs; Figure 2d).

We then analysed the distribution of nerve fibres, $\mathrm{T}$ helper cells (revealed by
anti-CD4 staining) and DCs inside the mouse lymph node; the results are shown in Figure 3. In B cell follicles, only a few $\mathrm{T}$ helper cells were present, some of them having close associations with nerve fibres (Figure $3 \mathrm{a}, \mathrm{c}$ ). In the paracortex (Figure 3 b,d), some nerve fibres also exhibited close associations with $\mathrm{T}$ helper cells and DCs (including a few CD4CD11 $\mathrm{c}^{+}$DCs and many $\mathrm{CD}^{+}{ }^{+} \mathrm{CD} 11 \mathrm{c}^{+} \mathrm{DCs}$ ).

We also performed triple-immunolabelling to reveal nerve fibres, cytotoxic $\mathrm{T}$ cells (revealed by anti-CD8a staining) and DCs inside the lymph node. The B cell fol-
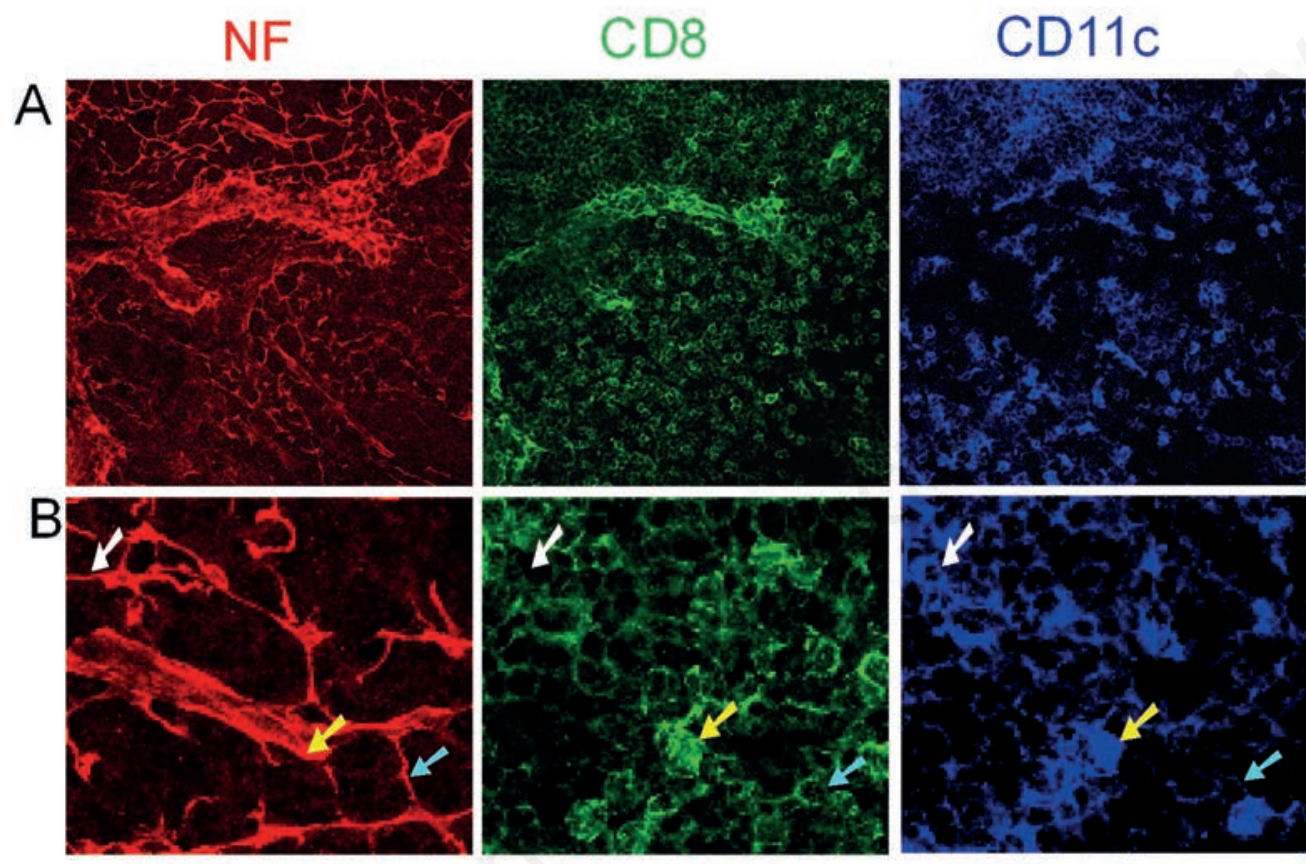

Merged
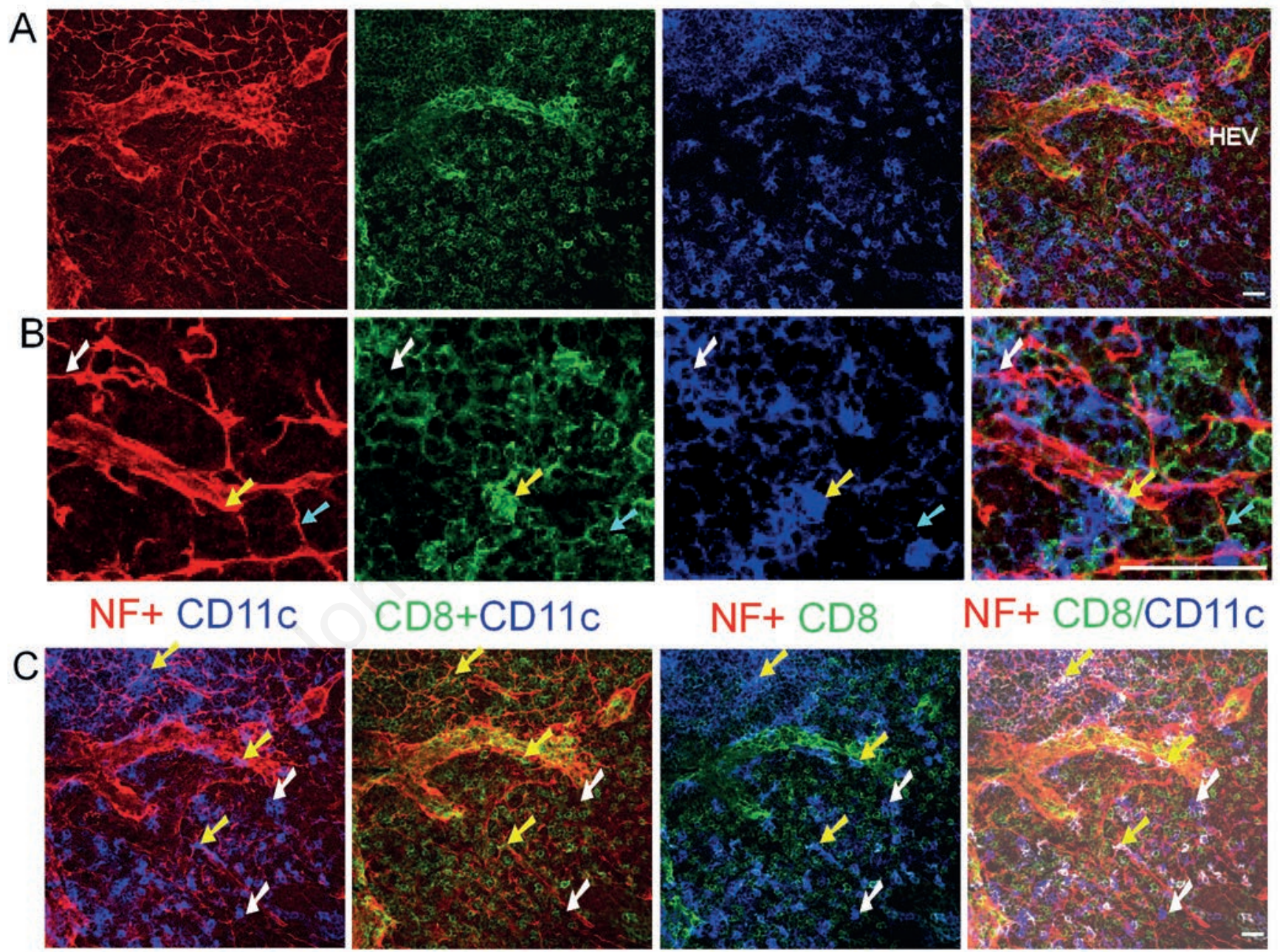

Figure 4. Distribution of nerve fibres, $\mathrm{CD}^{+}$cytotoxic $\mathrm{T}$ cells, and DCs in the paracortex of mesenteric lymph node of a C57BL/6 mouse. Antibodies against NF-H (red), CD8a (green), and CD11c (blue) label mainly nerve fibres, cytotoxic T cells, and DCs, respectively. The cyan arrows show $\mathrm{CD}^{+} \mathrm{a}^{+} \mathrm{CD} 11 \mathrm{c}^{-}$cytotoxic $\mathrm{T}$ cells that have a close association with the nerve fibres. The white arrows show CD8 a CD $11 \mathrm{c}^{+}$DCs that have a close association with the nerve fibres. The yellow arrows indicate CD8 $\mathrm{a}^{+} \mathrm{CD} 11 \mathrm{c}^{+} \mathrm{DCs}$ that have a close association with the nerve fibres. (B) High-resolution view of cropped regions of images shown in (A). C) Combinations of 2 or 3 channels shown in (A). The image in the fourth panel, in which CD8a CD11 ${ }^{+}$DCs appear white, is generated by merging image $A$ [the red channel (NF)] with image B (product of colocalization analysis of green and blue channels). All images are generated by using maximum intensity projection of 13 optical slices. Stack size: $6.0 \mu \mathrm{m}$; optical slice interval: $0.5 \mu \mathrm{m}$. HEV, high endothelial venules. Objective lens: 40x; scale bar: $20 \mu \mathrm{m}$. 
licles contained only a few cytotoxic $\mathrm{T}$ cells. In the paracortex (Figure 4), some nerve fibres exhibited close associations with cytotoxic $\mathrm{T}$ cells and DCs (CD8a CD $11 \mathrm{c}^{+}$and $\left.\mathrm{CD} 8 \mathrm{a}^{+} \mathrm{CD} 11 \mathrm{c}^{+} \mathrm{DCs}\right)$.

\section{Interaction of nerve fibres and} macrophages in mouse lymph nodes

The macrophage response can be triggered, maintained and terminated by a twoway interaction of macrophages and nerve fibres. ${ }^{7}$ In the present study, we investigated the association of nerve fibres and a subset of macrophages, namely Mac1 (CD11b) ${ }^{+}$ macrophages. Few $\mathrm{Mac}^{+}$macrophages were seen in the cortex. The distribution of $\mathrm{Mac}^{+}$macrophages, DCs and nerve fibres in the paracortex and medulla of a mouse lymph node is shown in Figure 5. The para- cortex (Figure 5a) and medulla (Figure 5b) contained many $\mathrm{Mac1}^{+} \mathrm{CD} 11 \mathrm{c}^{-}$ macrophages, some of which exhibited close apposition to the nerve fibres. We also observed the presence of $\mathrm{Mac1}^{+} \mathrm{CD} 11 \mathrm{c}^{+}$ DCs, which were closely apposed to the nerve fibres (Figure $5 \mathrm{a}-\mathrm{c}$ ).

We have observed two kinds of nerveimmune cells contact/association. The first was a nerve fibre-immune cell contact/association, as shown in Figures 2, 3, and 4. The second kind of contact/association was between nerve endings/terminals and immune cells, as shown in Figure $2 b$ and Figure 5c, which represent a few examples. These nerve endings appeared as red dots around the immune cells including B cell, T cells, and DCs.
Spatial relationship between nerve fibres and blood vessels in mouse lymph nodes

To understand the spatial relationship between nerve fibres and blood vessels inside the lymph node, double-immunolabelling with anti-CD31 (a blood vessel endothelial cell marker) and anti-NF was performed on cryosections. The results are shown in Figure 6 and Supplementary Figure 6. Bundles of nerve fibres accumulated at the hilum of the lymph node (Figure 6 and Supplementary Figure 6). Nerve bundles were also observed on the opposite side of the hilum (Supplementary Figures 1 and 6).

In $\mathrm{B}$ cell follicles, capillaries were closely associated with nerve fibres (Figure 6a). In the paracortex region (Figure 6b), close associations of nerve fibres and HEVs

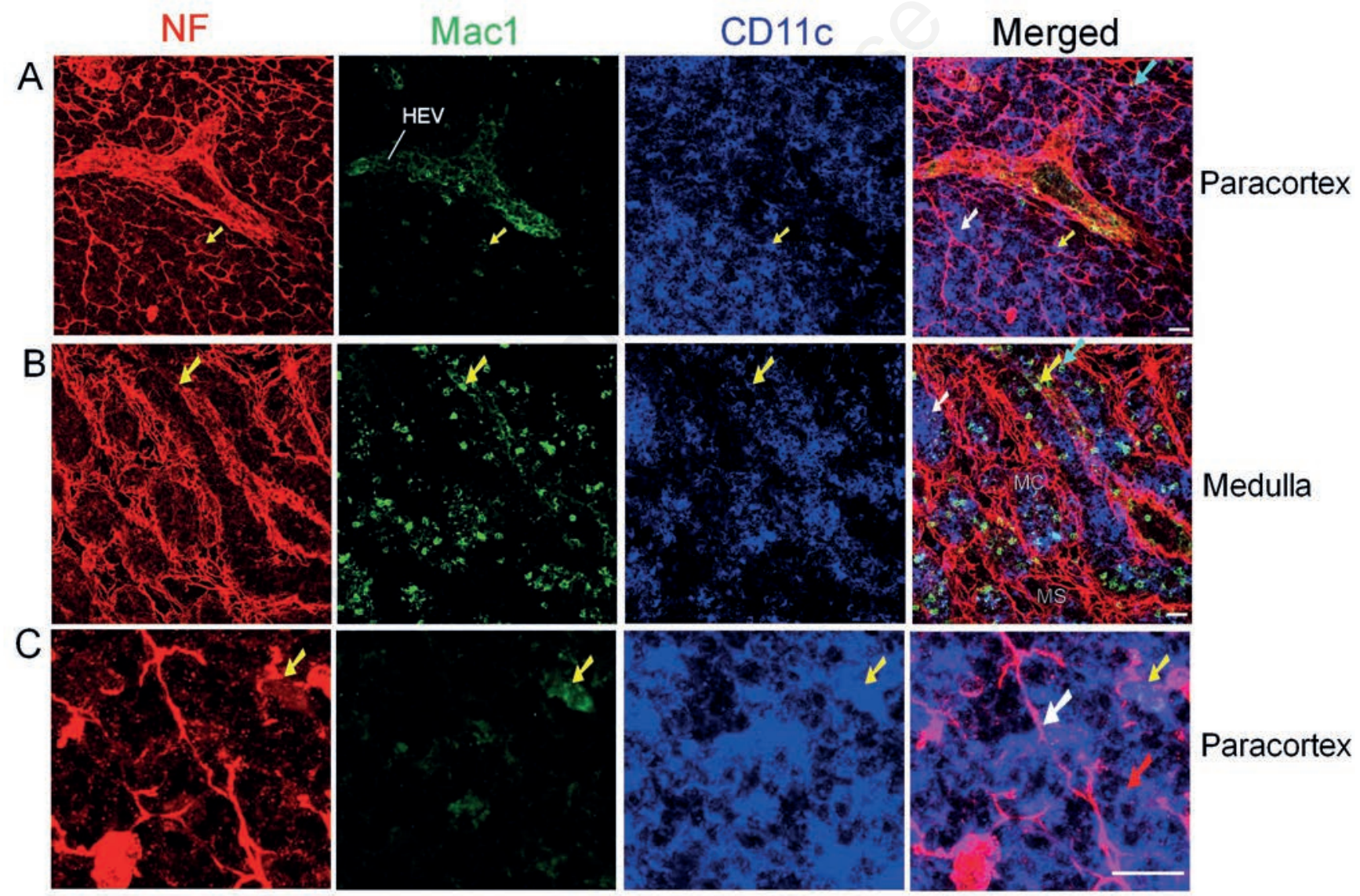

Figure 5. Distribution of nerve fibres, Mac1 ${ }^{+}$macrophages, and DCs in the paracortex $(\mathrm{A}, \mathrm{C})$ and medulla (B) of a mesenteric lymph node from a C57BL/6 mouse. Antibodies against NF-H (red), Mac1 (green), and CD11c (blue) label mainly nerve fibres, Mac1 ${ }^{+}$ macrophages, and DCs inside the lymph node, respectively. The white arrows show Mac1-CD11 ${ }^{+}$DCs that have a close association with the nerve fibres, whereas the yellow arrows indicate $\mathrm{Mac1}^{+} \mathrm{CD} 11 \mathrm{c}^{+}$DCs that have a close association with the nerve fibres. The cyan arrows indicate $\mathrm{Mac1}^{+} \mathrm{CD} 11 \mathrm{c}^{-}$macrophages that have a close association with the nerve fibres. $(\mathrm{C})$ The images show two types of nerve-immune contacts. The white arrow shows a nerve fibre that has a close association with a few Mac1-CD11 ${ }^{+}$DCs. The red arrow indicates nerve endings (appearing as red spots) that have a close association with Mac1-CD11 ${ }^{+}$DC. HEV, high endothelial venules; MS, medullary sinus; MC, medullary cord. Objective lens: $40 x$; scale bar: $20 \mu \mathrm{m}$. 
were also observed possibly indicating the neural control of blood flow inside HEVs and other blood vessels inside the lymph node. Furthermore, in the medulla region, we observed a close association of nerve fibres with blood vessels and even with the lymphatic vessels/sinus (identified indirectly through histological features; Figure 6c).

\section{Discussion}

The PNS and immune system are anatomically and functionally interconnected as has been demonstrated by the dense innervation of the primary and secondary lymphoid tissues/organs (including thymus, spleen and lymph nodes). ${ }^{11-14,20-21}$ The local interactions between the cells from two systems provide the structural basis of the complex network of immune and neural responses. However, until now, despite some previously reported studies, ${ }^{11-15}$ no detailed microanatomical investigations of the innervation of the lymph nodes have appeared in the literature. In the present study, we have observed extensive innervation and nerve-immune cell interaction in the lymph node, which has not been reported before. This kind of local nerve-immune cell interaction is very helpful for us to understand the microanatomical basis of bidirectional neuroimmune communications.

NFs are intermediate filaments measuring approximately $10 \mathrm{~nm}$ in diameter and many micrometres in length. Their primary function is to provide structural support for axons and to regulate axon diameter, which influences nerve conduction velocity. ${ }^{22}$ By using anti-NF-H as a reliable neuronal marker, we have characterized the distribution of nerve fibres in the lymph nodes. Our approach is robust and much easier to per- form compared with some other studies involving technically difficult methods (e.g., retrograde tracing). ${ }^{10} \mathrm{~A}$ few of our observations are especially interesting.

First, we observed bundles of nerve fibres not only at the hilum region, but also at the side opposite to the hilum, a finding that indicates that the nerves enter the lymph node at two or more sites. This type of multiple entry sites of nerves has also been reported in another secondary lymphoid organ-spleen. ${ }^{23}$ The sympathetic input reaches the spleen via the arteries, whereas the parasympathetic input arrives at the spleen via both of its tips. ${ }^{23}$ The multiple entry sites of nerves to the lymph node will have to be confirmed by using serial sectioning or whole-mount tissue/organ staining (e.g., immunostaining of the superficial inguinal lymph nodes together with their adjacent skin/connective tissue).

Second, an extensive meshwork of NF-
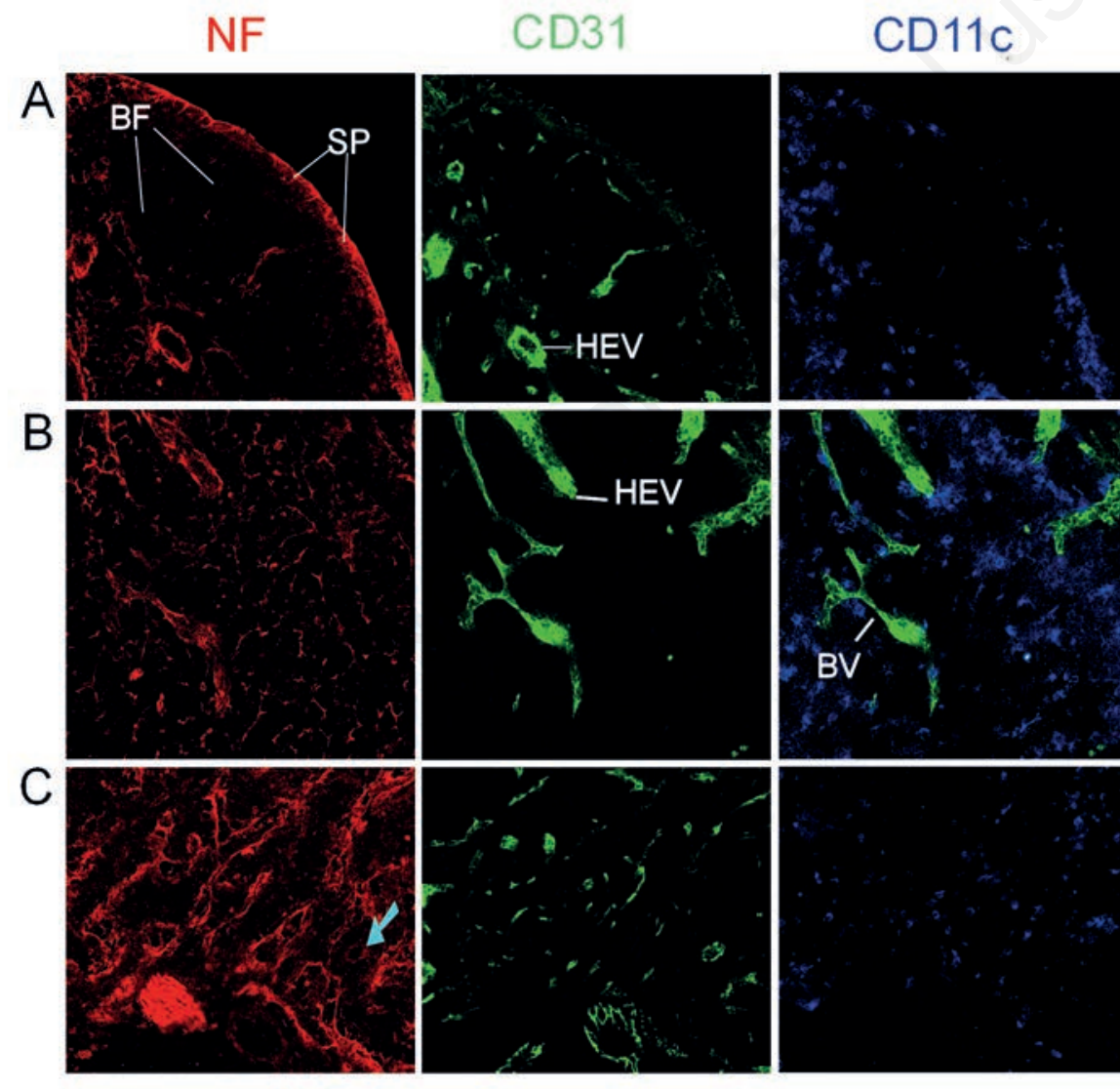

Merged
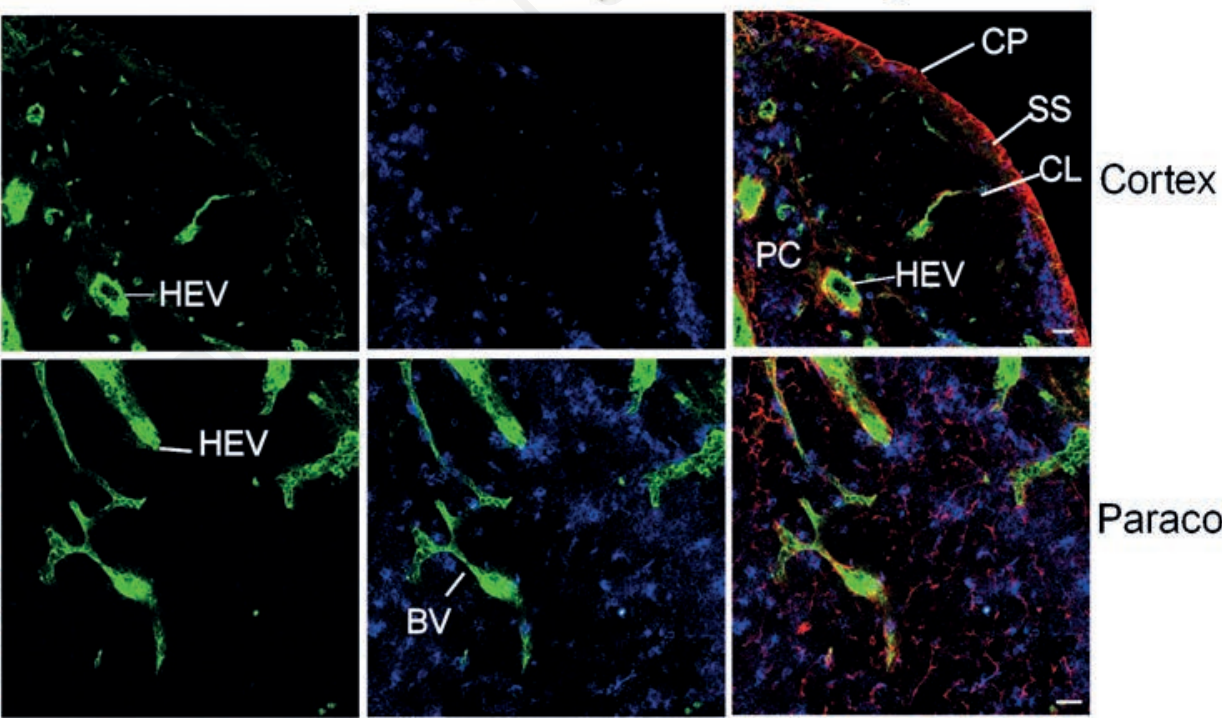

Paracortex
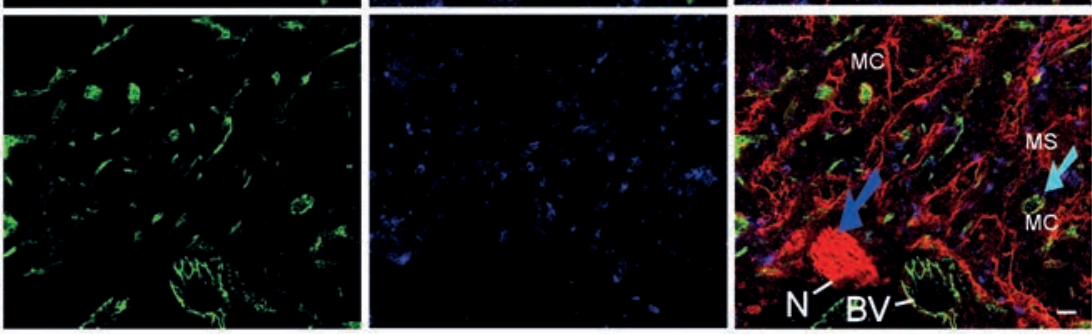

Medulla

Figure 6. Distribution of nerve fibres, blood vessels, and DCs in the cortex (A), paracortex (B), and medulla (C) in an inguinal lymph node of a C57BL/6 mouse. Antibodies against NF-H (red), CD31 (green), and CD11c (blue) label mainly nerve fibres, blood vessel endothelial cells, and DCs, respectively. C) The cyan arrow shows a blood vessel inside a medullary cord. The blue arrow indicates a nerve bundle entering the lymph nodes at the hilum. CP, capsule; CL, capillary; BF, B cell follicle; SS, subcapsular sinus; HEV, high endothelial venules; PC, paracortex; MS, medullary sinus; MC, medullary cord; N, nerves; SP, subcapsular plexus; BV, blood vessel. Objective lens: 40x; Scale bar: $20 \mu \mathrm{m}$. 
$\mathrm{H}^{+}$nerve fibres was observed throughout the lymph nodes and the intensities were much higher compared with those reported in some studies. ${ }^{10,15}$ Since lymph nodes are located in various anatomic regions/sites, we elected to analyse a few types of lymph nodes (including the mesenteric/inguinal nodes), and obtained similar results in each, concerning their innervation. Nerve fibres were observed in all compartments (including the $\mathrm{B}$ cell follicles and their germinal centres). This kind of high-intensity innervation agrees with our previous report on non-myelinating Schwann cells/Remak fibres of lymph nodes. ${ }^{19}$ However, our results do not agree with some reports indicating almost no innervation inside the $\mathrm{B}$ cell follicles and their germinal centres. ${ }^{10,15}$ The much smaller numbers of nerve fibres inside the cortex and other compartments reported in these studies might be attributable to insufficient or unsuccessful immunostaining of nerve inside the lymph node. We have applied several neuronal markers (e.g., glial fibrillary acidic protein $^{19}$ ) to investigate the innervation of lymph node/spleen/thymus and obtained similar results concerning the distribution of nerve fibres. Therefore, we believe that our staining with anti-NF-H reflects the real in situ distribution of nerve fibres inside the lymph node. These nerve fibres should include the postganglionic sympathetic/ parasympathetic (efferent) and visceral sensory nerves. Since NF is a general neuronal marker, additional cellular markers such as tyrosine hydroxylase, choline acetyltransferase and acetylcholinesterase can be used to identify specific nerve types innervating the lymph node.

Third, our study has demonstrated two types of PNS-immune cell interactions, namely nerve fibre-immune interaction and nerve ending-immune cell interactions. In one previous study of the sympathetic innervation of rat cervical lymph nodes involving the use of the anterograde tracking of nerves with Fluoro-Ruby (a neuronal tracer),${ }^{10}$ only the varicosities of sympathetic fibres were revealed. In our study, small $(<1 \mu \mathrm{m})$ bright red dots (staining signals) were observed, many being closely apposed to the immune cells. These nerve endings are probably from sympathetic or parasympathetic fibres. In the case of sympathetic fibres, the bright dots indicate the varicosities, whereas in the case of the parasympathetic fibres, the bright dots indicate the terminal buttons (end bulbs).

The crosstalk of the vascular system and PNS contributes to the development and progression of some common diseases when dysregulated. ${ }^{24}$ Nerve endings have been reported to be associated with smooth muscle cells of muscular vessels. ${ }^{25}$ The nerve fibres travel along blood vessels, form plexi around the blood vessels and extend into the parenchyma of the lymph node. ${ }^{14,19}$ Similarly, in our study, in each compartment of the lymph node, we have also observed a close association of nerve fibres with blood vessels, even capillaries without smooth muscles. The innervation of blood vessels is thought to regulate the blood flow and vascular permeability inside the lymph node.

HEVs are anatomically distinct postcapillary venules in the lymph node and other secondary lymphoid organs including Peyer's patches. ${ }^{26}$ Lymphocytes and other immune cells flow through arteries/arterioles and pass through the capillaries before entering HEVs, which are lined with specialized endothelial cells that support leucocyte adhesion and migration. ${ }^{26} \mathrm{We}$ have observed nerve plexi around the HEV in this study and in one of our previous studies. ${ }^{19}$ Therefore, the neuronal regulation of the blood flow and vascular permeability of HEVs might affect the subsequent immune cell dynamics inside the lymph node.

Recent studies have shown that lymphatic vessels also have innervation that might contribute to the regulation of lymph flow. ${ }^{19,27}$ In our study, we have observed the association of nerve fibres and the lymphatic vessel/sinus including the subcapsular sinus, trabecular sinus, and medullary sinus, as identified indirectly by microanatomical features instead of cellular markers. This kind of interaction suggests the active neural regulation of vessel calibre and functionality of the lymphatic vessel/sinus inside the lymph node. Certainly, further morphological, biochemical, and functional studies are needed to reveal the roles of the nerve fibres in the activities and functions of lymphatic vessels.

Since nerve/nerve fibres are relatively static and since immune cells (such as DCs, macrophages, and lymphocytes) are mobile, the nerve-immune cell contact should be dynamic. Further functional studies need to be carried out to reveal the mechanisms of this kind of cell-to-cell interaction. For example, catecholamines released from postganglionic fibres of sympathetic nerves (and the adrenal medulla) are important regulators of the functions of immune cells. ${ }^{28-30}$ Cytokines (including tumour necrosis factor, interleukin (IL)-1 $\beta$, IL-6, IL-17, prostaglandins, and other molecules) that are produced/released from neutrophils, macrophages, mast cells, and other immune cells can interact with sensory neurons through these receptors in health and disease. ${ }^{31-33}$ In addition, the interaction of noradrenaline/adrenaline with adrenergic receptors expressed on neutrophils, monocytes, macrophages, $\mathrm{T}$ cells, and other immune cells contributes to cytokine production and inflammation. ${ }^{5,7}$

DC migration and motility are influenced by sympathetic and sensory neural input and immature DCs are responsive to both noradrenaline and neuropeptides. ${ }^{7}$ Recent studies have demonstrated the local interactions of DCs and nerve fibres in the lung and lymph node. ${ }^{15,19,34}$ Within our study, we have observed extensive interactions of nerve fibres and DCs, especially in the paracortex of the lymph node. Because of the heterogeneity of DCs, ${ }^{35,36}$ we have combined the DC marker -CD11c with other CD markers (e.g., B220, CD4, CD8a and $\mathrm{CD} 11 \mathrm{~b}$ ) to identify the different subsets of DCs. Our approach has revealed the local interaction of nerve fibres with various DCs subsets, including $\mathrm{B} 220^{+} \mathrm{CD} 11 \mathrm{c}^{+}$, B220-CD11 ${ }^{+}, \mathrm{CD}^{+} \mathrm{CD} 11 \mathrm{c}^{+}, \mathrm{CD} 4-\mathrm{CD} 11 \mathrm{c}^{+}$, $\mathrm{CD}^{+} \mathrm{CD}^{+} 1 \mathrm{c}^{+}, \mathrm{CD} 8{ }^{-\mathrm{CD}} 11 \mathrm{c}^{+}, \mathrm{Mac}^{+} \mathrm{CD} 11 \mathrm{c}^{+}$ and $\mathrm{Mac} 1^{-} \mathrm{CD} 11 \mathrm{c}^{+}$DCs.

Recent studies have also demonstrated the local interactions of macrophages and nerve fibres in the lung, lymph node, and other organs. ${ }^{15,19}$ In our study, we have observed the close interactions of nerve fibres with one subset of macrophage $\left(\mathrm{Macl}^{+}\right)^{36}$ in the paracortex and medulla of lymph nodes, suggesting that nerve fibres affect macrophage functions such as antigen presentation and cytokine production. ${ }^{7}$ Consequently, macrophages can also have surprising effects through cytokine and other inflammatory factors. ${ }^{7}$

Although a few studies have reported that $\mathrm{B} / \mathrm{T}$ cells do not form contacts with nerve fibres, ${ }^{15}$ we have observed close associations of nerve fibres with $\mathrm{B}$ cells, $\mathrm{CD} 4^{+} \mathrm{T}$ helper cells, and $\mathrm{CD} 8 \mathrm{a}^{+}$cytotoxic $\mathrm{T}$ cells. This kind of close contiguity leads to several suggestions. ${ }^{5,7}$ First, the nerve fibres may affect the antigen presentation of $B$ cells. Second, the nerve fibres may have impacts on the activation of $\mathrm{CD}^{+} / \mathrm{CD}^{+} \mathrm{T}$ cells. Third, immune cells can have impacts on nerve fibres through the production of cytokines. Fourth, some neurotransmitters/ neuropeptides can act directly on $\mathrm{T}$ cells.

Although further molecular in vitro and in vivo studies of the mechanisms are needed, our findings concerning the innervation and nerve-immune cell interaction inside the lymph node provide a reliable microanatomical basis for nerve-immune interactions/communications inside lymph nodes. The study of neuroimmune modulations should greatly facilitate our understanding of the mechanisms by which the PNS affects cellular- and humoral-mediated immune responses and vice versa in infectious and non-infectious diseases. ${ }^{37-40}$ Furthermore, chemical/pharmacological or other manipulations of these neuroimmune interactions should benefit the development 
of potential practical therapeutic approaches for certain neuroimmune, infectious, and immunological diseases. ${ }^{5,37-40}$

\section{References}

1. Kotas ME, Medzhitov R. Homeostasis, inflammation, and disease susceptibility. Cell 2015;160:816-27.

2. Pinho-Ribeiro FA, Verri WA Jr, Chiu IM. Nociceptor sensory neuronimmune interactions in pain and inflammation. Trends Immunol 2017; 38:5-19.

3. Yoo BB, Mazmanian SK. The enteric network: interactions between the immune and nervous systems of the gut. Immunity 2017;46:910-26.

4. Voisin T, Bouvier A, Chiu IM. Neuroimmune interactions in allergic diseases: novel targets for therapeutics. Int Immunol 2017;29:247-61.

5. Chavan SS, Pavlov VA, Tracey KJ. Mechanisms and therapeutic relevance of neuro-immune communication. Immunity 2017;46:927-42.

6. Bellinger DL, Lorton D. Autonomic regulation of cellular immune function. Auton Neurosci 2014;182:15-41.

7. Ordovas-Montanes J, Rakoff-Nahoum S, Huang S, Riol-Blanco L, Barreiro O, von Andrian UH. The regulation of immunological processes by peripheral neurons in homeostasis and disease. Trends Immunol 2015;36:578-604.

8. Veiga-Fernandes H, Mucida D. Neuroimmune interactions at barrier surfaces. Cell 2016; 165:801-11.

9. Razavi R, Chan Y, Afifiyan FN, Liu XJ, Wan X, Yantha J, et al. TRPV1+ sensory neurons control beta cell stress and islet inflammation in autoimmune diabetes. Cell 2006; 127:1123-35.

10. Huang J, Zhu C, Zhang P, Zhu Q, Liu Y, Zhu Z, et al. S100+ cells: A new neuroimmune cross-talkers in lymph organs. Sci Rep 2013;3:1114.

11. Mignini F, Streccioni V, Amenta F. Autonomic innervation of immune organs and neuroimmune modulation. Auton Autacoid Pharmacol 2003;23:125.

12. Nance DM, Sanders VM. Autonomic innervation and regulation of the immune system (1987-2007). Brain Behav Immun 2007; 21:736-45.

13. Felten DL, Ackerman KD, Wiegand SJ, Felten SY. Noradrenergic sympathetic innervation of the spleen: I. Nerve fibres associate with lymphocytes and macrophages in specific compartments of the splenic white pulp. J Neurosci Res 1987;18:28-36.

14. Felten DL, Livnat S, Felten SY, Carlson SL, Bellinger DL, Yeh P. Sympathetic innervation of lymph nodes in mice. Brain Res Bull 1984;13:693-9.

15. Wülfing C, Günther HS. Dendritic cells and macrophages neurally hard-wired in the lymph node. Sci Rep 2015;5:16866.

16. Fujii T, Mashimo M, Moriwaki Y, Misawa H, Ono S, Horiguchi K, et al. Expression and function of the cholinergic system in immune cells. Front Immunol 2017;8:1085.

17. Pacheco R, Contreras F, Prado C. Cells, molecules and mechanisms involved in the neuro-immune interaction. In: Gowder S, editor. Cell Interaction. InTech; 2012. doi: 10.5772/48435.

18. Thomas SN, Rohner NA, Edwards EE. Implications of lymphatic transport to lymph nodes in immunity and immunotherapy. Annu Rev Biomed Eng 2016;18:207-33.

19. Shi Z, Greene WK, Nicholls PK, Hu D, Parker JEE, Yuan Q, et al. Immunofluorescent characterization of non-myelinating Schwann cells and their interactions with immune cells in mouse mesenteric lymph node. Eur J Histochem 2017;61:28279.

20. Ma B, Yin C, Hu D, Newman M, Nicholls PK, Wu Z, et al. Distribution of non-myelinating Schwann cells and their associations with leukocytes in mouse spleen revealed by immunofluorescence staining. Eur J Histochem 2018;62:2890.

21. Hu D, Nicholls PK, Yin C, Kelman K, Yuan Q, Greene WK, et al. Immunofluorescent localization of nonmyelinating Schwann cells and their interactions with immune cells in mouse thymus. J Histochem Cytochem 2018;66:775-85.

22. Kevenaar JT, Hoogenraad CC. The axonal cytoskeleton: from organization to function. Front Mol Neurosci 2015;8:44.

23. Buijs RM, van der Vliet J, Garidou ML, Huitinga I, Escobar C. Spleen vagal denervation inhibits the production of antibodies to circulating antigens. PLOS One 2008;3:e3152.

24. Carmeliet P, Tessier-Lavigne M. Common mechanisms of nerve and blood vessel wiring. Nature 2005;436:193-200.

25. Villaro AC, Sesma MP, Vazquez JJ. Innervation of mouse lymph nodes: nerve endings on muscular vessels and reticular cells. Am J Anat 1987; 179:175-85.

26. Girard JP, Moussion C, Förster R. HEVs, lymphatics and homeostatic immune cell trafficking in lymph nodes. Nat Rev Immunol 2012;12:762-73.

27. Mignini F, Sabbatini M, Coppola L,
Cavallotti C. Analysis of nerve supply pattern in human lymphatic vessels of young and old men. Lymphat Res Biol 2012;10:189-97.

28. Sternberg EM. Neural regulation of innate immunity: a coordinated nonspecific host response to pathogens. Nat Rev Immunol 2006;6:318-28.

29. Besser MJ, Ganor Y, Levite M. 2005. Dopamine by itself activates either D2, D3 or D1/D5 dopaminergic receptors in normal human T-cells and triggers the selective secretion of either IL-10, $\mathrm{TNF} \alpha$ or both. J Neuroimmunol 2005; 169:161-71.

30. Scheiermann C, Kunisaki Y, Lucas D, Chow A, Jang JE, Zhang D, et al. Adrenergic nerves govern circadian leukocyte recruitment to tissues. Immunity 2012;37:290-301.

31. Schaible HG. Nociceptive neurons detect cytokines in arthritis. Arthritis Res Ther 2014;16:470.

32. Nicol GD, Lopshire JC, Pafford CM. Tumor necrosis factor enhances the capsaicin sensitivity of rat sensory neurons. J Neurosci 1997;17:975-82.

33. Binshtok AM1, Wang H, Zimmermann $\mathrm{K}$, Amaya F, Vardeh D, Shi L, et al. Nociceptors are interleukin-1 $\beta$ sensors. J Neurosci 2008;28:14062-73.

34. Veres TZ, Shevchenko M, Krasteva G, Spies E, Prenzler F, Rochlitzer S, et al. Dendritic cell-nerve clusters are sites of $\mathrm{T}$ cell proliferation in allergic airway inflammation. Am J Pathol 2009;174: 808-17.

35. Hashimoto D, Miller J, Merad M. Dendritic cell and macrophage heterogeneity in vivo. Immunity 2011;35:323-35.

36. Murray PJ, Wynn TA. Protective and pathogenic functions of macrophage subsets. Nat Rev Immunol 2011;11: 723-37.

37. Pavlov VA, Chavan SS, Tracey KJ. Molecular and functional neuroscience in immunity. Annu Rev Immunol 2018;36:783-812.

38. Iannacone M, Moseman EA, Tonti E, Bosurgi L, Junt T, Henrickson SE, et al. Subcapsular sinus macrophages prevent CNS invasion on peripheral infection with a neurotropic virus. Nature 2010;465:1079-83.

39. Reardon C, Murray K, Lomax AE. Neuroimmune communication in health and disease. Physiol Rev 2018;98:2287316.

40. Fung TC, Olson CA, Hsiao EY. Interactions between the microbiota, immune and nervous systems in health and disease. Nat Neurosci 2017;20:14555. 